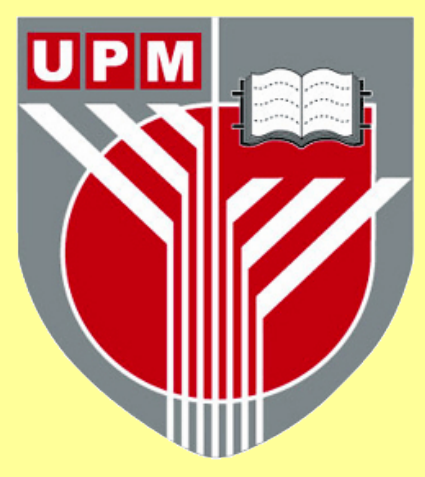

KEWUJUDAN BAHASA ANTARA DALAM KALANGAN PELAJAR SUKU DUSUN TINDAL

DAISY BINTI PAUL

FBMK 202017 


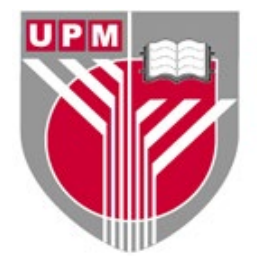

KEWUJUDAN BAHASA ANTARA DALAM KALANGAN PELAJAR SUKU DUSUN TINDAL

\section{Oleh}

DAISY BINTI PAUL

Tesis yang dikemukakan kepada Sekolah Pengajian Siswazah, Universiti

Putra Malaysia, sebagai memenuhi keperluan untuk Doktor Falsafah 
Semua bahan yang terkandung dalam tesis ini, termasuk teks tanpa had, logo, iklan, gambar dan semua karya seni lain, adalah bahan hak cipta Universiti Putra Malaysia kecuali dinyatakan sebaliknya, Penggunaan mana-mana bahan yang terkandung dalam tesis ini dibenarkan untuk tujuan bukan komersil daripada pemegang hak cipta. Penggunaan komersil bahan hanya boleh dibuat dengan kebenaran bertulis terdahulu yang nyata daripada Universiti Putra Malaysia.

Hak cipta (C) Universiti Putra Malaysia 


\section{DEDIKASI}

Buat ayahandaku PAUL BIN TANGGARON

Mendiang bonda tercinta NURIA BINTI GURAPON

Terima kasih kerana tidak jemu mendidikku

Bibirmu sentiasa memanjatkan doa buat diriku

Kuingati setiap pesananmu, dikaulah sumber inspirasi kejayaanku

Kejayaanku adalah hadiah buat kasih sayangmu

Teristimewa untuk anak-anakku tersayang

\section{CASANDRA AMANDA, CLARA CLAUDIA, CARMEN CALISTA dan CLEVERICH AMIENN JUNIOR}

Mama banyak meragut masa kalian sayang...

Seikhlas kemaafan mama pinta daripada kalian

Sepenuh penghargaan atas pengertian kalian

Akhirnya kejayaan mama adalah untuk kalian...

Buat adik-adikku serta keluarga, terima kasih atas sokongan dan dorongan kalian

Ucapan khas untuk Penyeliaku, Prof. Madya Dr. NOOR AINA DANI

Terima kasih atas bimbingan dan sokongan padu terhadapku

Tidak dilupakan teman-temanku yang sentiasa mendorong dan membakar semangatku

Semuanya amat bermakna buat diriku.... 
Abstrak tesis yang dikemukakan kepada Senat Universiti Putra Malaysia sebagai memenuhi keperluan untuk ijazah Doktor Falsafah

\title{
KEWUJUDAN BAHASA ANTARA DALAM KALANGAN PELAJAR SUKU DUSUN TINDAL
}

\author{
Oleh
}

\section{DAISY BINTI PAUL}

\author{
Julai 2019
}

\section{Pengerusi : : Prof. Madya Noor Aina Binti Dani, PhD \\ Faculty : Bahasa Moden dan Komunikasi}

Kajian ini bertujuan untuk meneliti bentuk bahasa antara dalam penulisan karangan pelajar suku Dusun Tindal. Kajian kes dijalankan di Sekolah Menengah Tenghilan, Tuaran, Sabah yang melibatkan sebanyak 69 pelajar, 12 orang guru Bahasa Melayu dan 2 informan dari komuniti suku Dusun Tindal. Instrumen penyelidikan ialah set soal selidik, ujian karangan, inventori terjemahan versi kosa kata dan ayat bahasa Melayu dan bahasa Dusun Tindal, dan borang temu bual berstruktur.

Terdapat beberapa penemuan penting daripada penyelidikan ini. Pertama, faktor yang mempengaruhi penggunaan bahasa pelajar suku Dusun Tindal ialah bahasa ibu bapa di rumah, bahasa pertuturan ibu bapa ketika bersama anakanak, transmisi bahasa antara generasi dan trend dalam domain bahasa ibunda yang sedia ada. Ironinya, transmisi bahasa antara generasi berada di persimpangan antara 'selamat' dengan 'hampir terancam'. Trend dalam domain bahasa yang sedia ada menunjukkan kesetaraan multibahasa. Kedua, kebanyakan skor penulisan karangan bahasa Melayu pelajar pada peringkat 'baik' tetapi kandungan karangan masih ada bentuk bahasa antara. Bentuk pemindahan latihan terjadi berdasarkan kekerapan pelajar menggunakan struktur ayat bahasa ibunda yang bermula dengan frasa kerja atau adjektif. Ketiga, ayat yang mengandungi bentuk terlebih generalisasi menggambarkan penara sementara bahasa antara. Keempat, guru-guru bahasa menyarankan beberapa strategi bagi meleraikan bentuk bahasa antara, terutamanya mengambil sikap yang betul terhadap kesilapan bahasa pelajar. Kelima, kontinum bahasa antara pelajar kebanyakannya pada tahap akrolek antara skor 81 hingga 97. Tahap ini menghampiri kompetensi bahasa penutur asli. Sebagai langkah penambahbaikan, penyelidikan punca penara sementara adalah munasabah untuk mengatasi halangan bahasa antara yang dihadapi oleh pelajar suku Dusun Tindal. 
Abstract of thesis presented to the Senate of Universiti Putra Malaysia in
fulfilment of the requirement for the degree of Doctor of Philosophy

THE EXISTENCE OF INTERLANGUAGE AMONG DUSUN TINDAL TRIBE LEARNERS

Oleh

\section{DAISY BINTI PAUL}

\section{July 2019}

\section{Chair : : Assoc. Prof. Noor Aina Dani, PhD \\ Faculty \\ : Modern Languages and Communication}

This research aims to examine the interlanguage forms in essay writing by learners from the Dusun Tindal tribe. The case study was conducted at Tenghilan Secondary School, Tuaran, Sabah which involved 69 students, 12 Bahasa Melayu teachers and 2 informants from the Dusun Tindal community. The research instruments are questionnaires set, essay test, translation inventory of the Malay and Dusun Tindal vocabulary and syntactic versions, and structured interview form.

There are some important findings from this research. Firstly, the factors affecting the Dusun Tindal tribe language usage are parent home language, language used by the parent while communicating with children, intergenerational language transmission and trends in existing mother tongue domains. Ironically, intergenerational language transmission is at the crossroads between 'safe' and 'threatened'. Trends in existing native language domains show multilingual equivalence. Secondly, most essay writing scores in the Malay language are level 'good' but the contents are not free from interlanguage. Transfer of training occurs based on the frequency in using native sentence structure of frontal verbal or adjectival phrases. Thirdly, sentences accommodate the overgeneralization form depicts a temporary plateau of interlanguage. Fourthly, language teachers suggest a number of strategies to dissolve interlanguage, specifically the right attitude towards student language errors. Fifthly, the continuum of interlanguage is based on the knowledge of native and the Malay language of the students mostly at acrolect level between 81 to 97 scores. This stage approximating near-native speaker competency. As an augmentation measure, research on the source of the temporary plateau is plausible in overcoming interlanguage faced by learners from the Dusun Tindal tribe. 


\section{PENGHARGAAN}

Ucapan syukur yang tidak terhingga dipanjatkan kepada llahi kerana penyelidik dapat menyiapkan tesis ini dengan jayanya. Kejayaan tesis ini ditujukan khas buat bapa tersayang Paul Bin Tanggaron serta mendiang ibu tercinta, Nuria Binti Gurapon yang sentiasa menjadi pendorong dan pembakar keazaman serta tidak jemu memanjatkan restu dan doa. Khas untuk anak-anak tersayang, Casandra Amanda, Clara Claudia, Carmen Calista dan Cleverich Amienn Junior yang sentiasa menyokong dan menjadi sumber inspirasiku. Seterusnya, untuk adikadik ku Elvispresley, Elison, Diana dan Alexander serta keluarga yang setia di sampingku sepanjang tempoh pengajian.

Setinggi-tinggi penghargaan dan sekalung kasih kepada Penyeliaku, Profesor Madya Dr Noor Aina Dani kerana banyak memberi bimbingan, tunjuk ajar, nasihat dan galakan serta sentiasa melahirkan idea yang bernas dalam membantu penyelidik menyiapkan tesis dari awal hingga akhir. Tidak dilupakan ahli jawatankuasa penyeliaanku Dr. Shahril Nizam Bin Sha'ri dan Prof. Madya Dr. Rohaidah Binti Kamaruddin, terima kasih atas sokongan kalian.

Penyelidik juga ingin merakamkan terima kasih kepada pengetua dan semua guru SMK. Kolombong, Inanam yang memberi kerjasama sepanjang penyelidik menjalankan kajian rintis. Tidak dilupakan kepada pengetua dan guru-guru SMK. Tenghilan, Tuaran yang memberikan kerjasama sepenuhnya semasa penyelidik menjalankan kajian di lapangan. Semoga kalian menjadi insan yang berguna dan berjasa kepada bangsa dan negara serta selamat maju jaya. Cabaran dan rintangan semakin mendewasakan minda ini. Sesungguhnya segala yang baik itu datang daripada yang Maha Kuasa dan yang buruk itu daripada kedaifan diri sendiri. Semoga Tuhan melimpahkan rahmat dan ganjaran kepada kita. Amin.

\section{BERILMU BERBAKTI}

Daisy Binti Paul

GS44202 
Saya mengesahkan bahawa satu Jawatankuasa Peperiksaan Tesis telah berjumpa pada 2 Julai 2019 untuk menjalankan peperiksaan akhir bagi Daisy Binti Paul bagi menilai tesis beliau yang bertajuk "Kewujudan Bahasa Antara dalam kalangan Pelajar Suku Dusun Tindal" mengikut Akta Universiti dan Kolej Universiti 1971 dan Perlembagaan Universiti Putra Malaysia [P.U.(A) 106] 15 Mac 1998. Jawatankuasa tersebut telah memperakukan bahawa calon ini layak dianugerahi ijazah Doktor Falsafah.

Ahli Jawatankuasa Peperiksaan Tesis adalah seperti berikut:

\title{
Arba'ie bin Sujud, PhD
}

Profesor Madya

Fakulti Bahasa Moden dan Komunikasi

Universiti Putra Malaysia

(Pengerusi)

\section{Zaitul Azma binti Zainon Hamzah, PhD}

Profesor Madya

Fakulti Bahasa Moden dan Komunikasi

Universiti Putra Malaysia

(Pemeriksa Dalam)

\section{Vijayaletchumy a/p Subramaniam, PhD}

Profesor

Fakulti Bahasa Moden dan Komunikasi

Universiti Putra Malaysia

(Pemeriksa Dalam)

\section{Chong Shin, PhD}

Profesor Madya

Institut Alam dan Tamadun Melayu

Universiti Kebangsaan Malaysia

Malaysia

(Pemeriksa Luar)

\author{
ZURIATI AHMAD ZUKARNAIN, PhD \\ Profesor Ts. dan Timbalan Dekan \\ Sekolah Pengajian Siswazah \\ Universiti Putra Malaysia
}

Tarikh: 07 Ogos 2020 
Tesis ini telah dikemukakan kepada Senat Universiti Putra Malaysia dan telah diterima sebagai memenuhi syarat keperluan untuk ljazah Doktor Falsafah. Ahliahli Jawatankuasa Penyeliaan adalah seperti berikut:

\section{Noor Aina binti Dani, PhD}

Profesor Madya

Fakulti Bahasa Moden dan Komunikasi

Universiti Putra Malaysia

(Pengerusi)

Rohaidah binti Kamaruddin, PhD

Profesor Madya

Fakulti Bahasa Moden dan Komunikasi Universiti Putra Malaysia

(Ahli)

\section{Sharil Nizam bin Sha'ri, PhD}

Pensyarah Kanan

Fakulti Bahasa Moden dan Komunikasi

Universiti Putra Malaysia

(Ahli)

Tarikh: 


\section{Perakuan pelajar siswazah}

Saya memperakui bahawa

- tesis ini adalah hasil kerja saya yang asli;

- $\quad$ setiap petikan, kutipan dan ilustrasi telah dinyatakan sumbernya dengan jelas;

- tesis ini tidak pernah dimajukan sebelum ini dan tidak dimajukan serentak dengan ini, untuk ijazah lain sama ada di Universiti Putra Malaysia atau institusi lain;

- $\quad$ hak milik intelek dan hak cipta tesis ini adalah hak milik mutlak Universiti Putra Malaysia, mengikut Kaedah-Kaedah Universiti Putra Malaysia (Penyelidikan) 2012;

- $\quad$ kebenaran bertulis daripada penyelia dan pejabat Timbalan Naib Canselor (Penyelidikan dan Inovasi) hendaklah diperoleh sebelum tesis ini diterbitkan (dalam bentuk bertulis, cetakan atau elektronik) termasuk buku, jurnal, modul, prosiding, tulisan popular, kertas seminar, manuskrip, poster, laporan, nota kuliah, modul pembelajaran atau material lain seperti yang dinyatakan dalam Kaedah-Kaedah Universiti Putra Malaysia (Penyelidikan) 2012;

- tiada plagiat atau pemalsuan/fabrikasi data dalam tesis ini, dan integriti ilmiah telah dipatuhi mengikut Kaedah-Kaedah Universiti Putra Malaysia (Pengajian Siswazah) 2003 (Semakan 2012-2013) dan Kaedah-Kaedah Universiti Putra Malaysia (Penyelidikan) 2012. Tesis ini telah diimbaskan dengan perisian pengesanan plagiat.

Tandatangan :

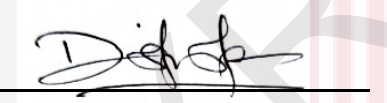

Tarikh: 21.9.2020

Nama dan No. Matrik : Daisy binti Paul, GS 44202 


\section{Perakuan Ahli Jawatankuasa Penyelidikan}

Dengan ini diperakukan bahawa:

- $\quad$ penyelidikan dan penulisan tesis ini adalah di bawah seliaan kami;

- tanggungjawab penyeliaan sebagaimana yang dinyatakan dalam Universiti Putra Malaysia (Pengajian Siswazah) 2003 (Semakan 2012-2013) telah dipatuhi.

Tandatangan:

Nama Pengerusi

Jawatankuasa

Penyeliaan:

Prof. Madya Dr. Noor Aina Dani

Tandatangan:

Nama Ahli

Jawatankuasa

Penyeliaan:

Dr. Rohaidah Kamaruddin

Tandatangan:

Nama Ahli

Jawatankuasa

Penyeliaan:

Dr. Sharil Nizam Bin Sha'ri 


\title{
JADUAL ISI KANDUNGAN
}

\author{
ABSTRAK \\ ABSTRACT \\ PENGHARGAAN \\ PENGESAHAN \\ PERAKUAN \\ SENARAI JADUAL \\ SRNARAI RAJAH \\ SENARAI SINGKATAN
}

Muka

surat

i

ii

iii

iv

vi

$x$

xii

xiii

BAB

1 PENDAHULUAN

SOROTAN LITERATUR 18

Pengenalan 18

Bahasa Antara dalam kalangan Penutur Bahasa Kedua $\quad 18$

Pembelajaran Bahasa Melayu sebagai Bahasa Kedua $\quad 25$

Perkaitan Sorotan Kajian dengan Penyelidikan Ini 35

3 METODOLOGI 38

$\begin{array}{ll}\text { Pengenalan } & 38\end{array}$

Reka Bentuk Kajian $\quad 38$

Kerangka Teori 38

Teori Bahasa Antara $\quad 39$

Taksonomi Faktor Penyebab Fosilisasi Bahasa Antara $\quad 46$

Kerangka Konseptual $\quad 47$

Tempat Kajian $\quad 48$

Populasi dan Pensampelan $\quad 49$

Kaedah Kajian $\quad 49$

Kajian Kes $\quad 50$

Temu Bual Berstruktur $\quad 51$

Pendekatan Kajian $\quad 51$

Pemboleh Ubah Kajian $\quad 52$

Alat Kajian 53

Kesahan dan Kebolehpercayaan Alat Kajian 54

Tatacara Kajian $\quad 56$

Kajian Rintis 56

Kajian Sebenar $\quad 69$

Penganalisisan Data $\quad 69$ 
4 KEPUTUSAN DAN PERBINCANGAN 72

$\begin{array}{ll}\text { Pengenalan } & 72 \\ \end{array}$

Faktor-Faktor yang Mempengaruhi Kewujudan Bahasa 72

Antara Pelajar Suku Dusun Tindal (sDT)

$\begin{array}{ll}\text { Bahasa Ibu Bapa di Rumah } & 72\end{array}$

Bahasa Pertuturan Ibu Bapa ketika bersama Anak-anak $\quad 73$

Transmisi Bahasa Antara Ibu Bapa dengan Anak-anak $\quad 73$

Trend dalam Domain Bahasa Ibunda yang Sedia Ada $\quad 74$

Bentuk Bahasa Antara dalam Penulisan Karangan 78

$\begin{array}{ll}\text { Bentuk Pemindahan Bahasa } & 79\end{array}$

$\begin{array}{ll}\text { Bentuk Pemindahan Latihan } & 79\end{array}$

$\begin{array}{ll}\text { Bentuk Strategi Pembelajaran dan Komunikasi } & 81\end{array}$

$\begin{array}{ll}\text { Bentuk Terlebih Generalisasi } & 83\end{array}$

$\begin{array}{lr}\text { Bentuk Pemudahan } & 84\end{array}$

Bentuk Balik Asal $\quad 85$

Sebab-musabab Bahasa Antara dalam Karangan $\quad 86$

Rumusan Tahap Bahasa Antara Pelajar sDT 93

Pencapaian dalam Penulisan Karangan 93

Kontinum Bahasa Antara B1 dan B2 94

Pengetahuan Kosa Kata B1 dan B2 95

Pengetahuan Ayat B1 dan B2 97

$\begin{array}{ll}\text { Hipotesis Kajian } & 105\end{array}$

Rasional Teori dengan Dapatan Kajian 106

Bahasa Antara 106

$\begin{array}{ll}\text { Fosilisasi } & 107\end{array}$

Bahasa Antara atau Penstabilan 108

Implikasi Dapatan Kajian 109

$\begin{array}{ll}\text { Keperluan } & 109\end{array}$

$\begin{array}{ll}\text { Ciri Peribadi } & 109\end{array}$

Akulturasi 110

Motivasi 110

Bahasa Antara Berterusan dan Penghapusan $\quad 110$

Ramalan dan Pemulihan 111

5 RINGKASAN, KESIMPULAN DAN CADANGAN UNTUK 112

$\begin{array}{ll}\text { PENYELIDIKAN MASA DEPAN } & 112 \\ \text { Pengenalan } & 112\end{array}$

$\begin{array}{lr}\text { Ringkasan } & 112 \\ \text { Kesimpulan } & 116\end{array}$

$\begin{array}{ll}\text { Kesimpulan } & 116\end{array}$

Cadangan Umum $\quad 117$

Cadangan untuk Penyelidikan Masa Depan 118

$\begin{array}{lr}\text { BIBLIOGRAFI } & 120\end{array}$

\begin{tabular}{ll} 
LAMPIRAN & 127 \\
\hline BIODATA PELAJAR & 143
\end{tabular}

$\begin{array}{lr}\text { BIODATA PELAJAR } & 143\end{array}$

$\begin{array}{ll}\text { SENARAI PENERBITAN } & 144\end{array}$ 


\section{SENARAI JADUAL}

Jadual

Muka surat

3.1 Taksonomi faktor penyebab fosilisasi bahasa antara 46

3.2 Analisis perbendaharaan kata 57

3.3 Analisis perkataan bahasa Dusun Tindal yang 59 mengandungi terjemahan BM

3.4 Analisis ayat bahasa Melayu yang mengandungi terjemahan BD

3.5 Analisis ayat bahasa Dusun yang mengandungi terjemahan BM

3.6 Analisis transmisi bahasa antara generasi

66

3.7 Analisis trend dalam domain bahasa ibunda sedia 66

3.8 Analisis karangan murid Tingkatan 4

67

3.9 Analisis terlebih generalisasi

68

3.10 Analisis pemudahan dalam karangan

68

3.11 Analisis penafian dalam karangan 69

$\begin{array}{lll}3.12 & \text { Pekali saiz alpha Cronbach }\end{array}$

4.1 Analisis bahasa ibu bapa di rumah 73

4.2 Analisis bahasa pertuturan ibu bapa ketika bersama 73 anak-anak di rumah

4.3 Analisis Transmisi bahasa Ibunda antara ibu bapa 74 dengan anak

4.4 Trend dalam domain bahasa ibunda yang Sedia Ada 75

4.5 Bentuk terlebih generalisasi dalam karangan BM 83 pelajar sDT

4.6 Bentuk Pemudahan dalam karangan BM pelajar sDT 84

$\begin{array}{lll}4.7 & \text { Faktor penyebab bahasa antara dalam penulisan } & 87\end{array}$ karangan BM baku pelajar SDT 
4.8 Pencapaian pelajar sDT dalam karangan BM

4.9 Frekuensi bahasa antara dalam karangan pelajar 94 sDT

4.10 Perbandingan pengetahuan kosa kata B1 dan B2 95 pelajar sDT

4.11 Analisis terjemahan kata BM-BDT

4.12 Analisis Terjemahan kata BDT-BM

4.13 Perbandingan pengetahuan ayat B1 dan B2 pelajar 98 sDT

4.14 Terjemahan ayat BM-BDT

99

4.15 Terjemahan ayat BDT-BM 100 


\section{SENARAI RAJAH}

Rajah

Muka surat

1.1 Kawasan bahasa-bahasa etnik di Sabah 1

1.2 Pembahagian suku kaum Dusun di negeri Sabah 3

1.3 Peralihan kecekapan dalam bahasa antara 6

$1.4 \quad$ Tanggapan tentang bahasa antara 16

2.1 Respons empat faktor ancaman bahasa yang 33 berkaitan dengan Bahasa Dusun

3.1 Kontinum Bahasa Antara 40

3.2 Ciri x (sementara) dan ciri $Y($ kekal) 43

$\begin{array}{lll}3.3 & \text { Kerangka Konseptual } & 47\end{array}$

3.4 Peta daerah-daerah di negeri Sabah 48

3.5 Penzuman (zooming) lokasi kajian di Tuaran, 49 Sabah.

4.1 Transmisi bahasa ibunda antara ibu bapa dengan 76 anak

4.2 Trend dalam domain bahasa ibunda sedia ada $\quad 77$

4.3 Bentuk Terlebih Generalisasi dalam Karangan BM 89 Baku

4.4 Tahap Bahasa Antara dalam Karangan BM Pelajar 101 sDT

4.5 Kontinum BA Pengetahuan Kosa Kata dan Ayat 103 Pelajar sDT 


\section{SENARAI SINGKATAN}

\begin{tabular}{ll} 
BM & Bahasa Melayu \\
BA & Bahasa Antara \\
B2 & Pelajar Bahasa Kedua \\
B1 & Bahasa Pertama \\
DMS & Dialek Melayu Sabah \\
F & Frekuensi \\
TG & Terlebih Generalisasi \\
SDT & suku Dusun Tindal \\
BDT & Bahasa Dusun Tindal \\
Cth. & Contoh \\
\hline MT & Mother tongue \\
IL & Interlanguage \\
TL & Target language \\
FL & Foreign language \\
NL & Native language \\
\hline
\end{tabular}


BAB 1

\section{PENDAHULUAN}

\section{Latar Belakang Kajian}

\section{Suku Dusun Tindal di Negeri Sabah}

Nama suku Dusun Tindal dalam keluarga bahasa Dusun di Sabah tidak banyak diketahui umum. Malahan, Lewis (2009, ms. 16) alpa memasukkan autonim Dusun Tindal dalam peta kawasan bahasa-bahasa etnik di Sabah yang tertera pada Rajah 1.1. Kod yang ada dalam peta tersebut ialah 87 Tambunan Dusun; 98 Central Dusun; 102 Tempasuk Dusun; 112 Sugut Dusun.

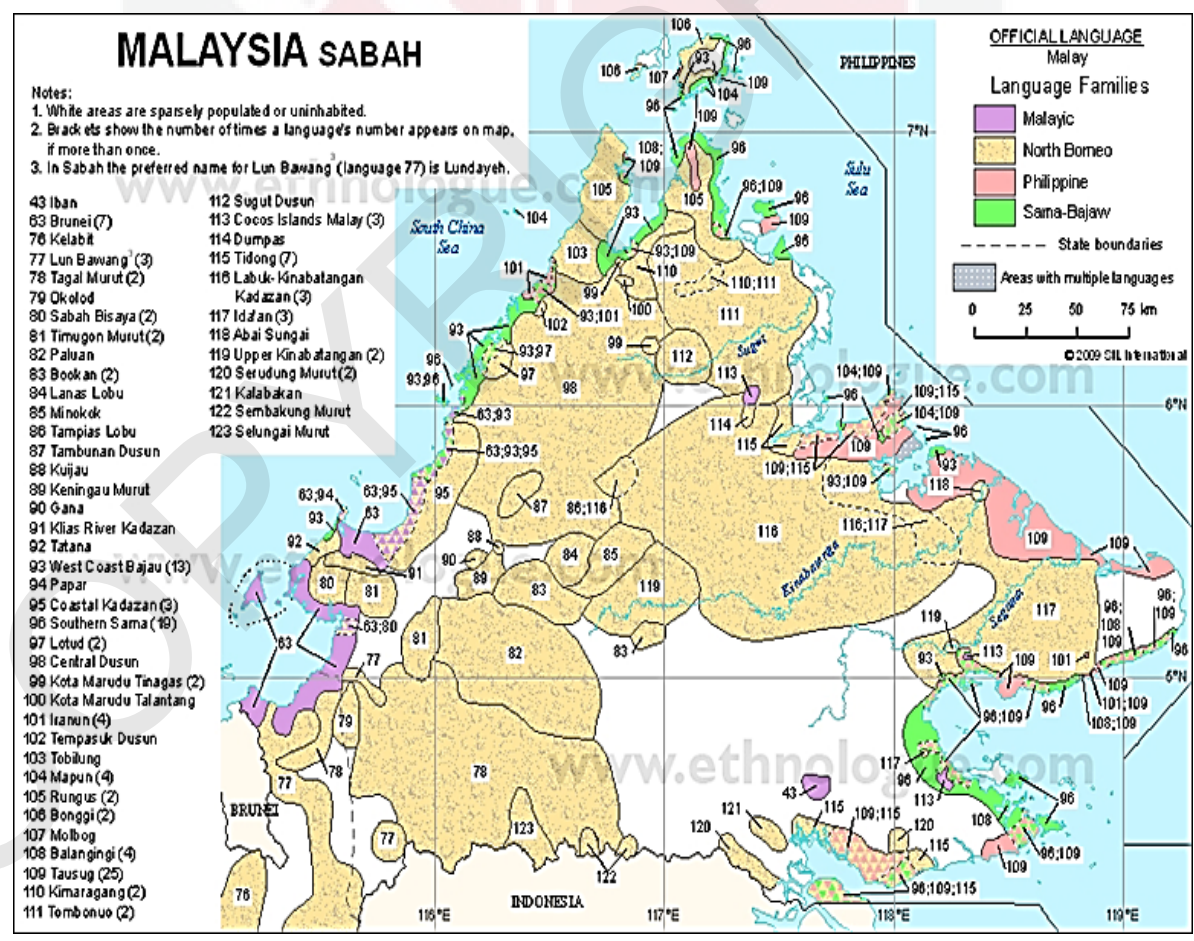

Rajah 1.1: Kawasan Bahasa-bahasa Etnik di Sabah (Sumber: Lewis, 2009: 16) 
Penyelidik menemui jalan buntu dalam pencarian dokumen yang sahih yang mengandungi kosa ilmu perihal masyarakat suku Dusun Tindal di negeri Sabah. Bagi keperluan latar belakang kajian ini, penyelidik telah menemu bual dua informan daripada suku Dusun Tindal yang menetap di Kampung Sumbilingon, Kelawat dan Kampung Botung, Kota Belud. (Rujuk Lampiran A). Informan pertama mengatakan bahawa antara cabang suku Dusun Tindal di Sabah ialah Minokok, Kuijau, Tatana, Tanagas, Rungus, Kimaragang, Lotud, Tombonuo, Dumpas, Idaan, Paitan, Dusun Ranau, dan Mangahak. Berdasarkan sumber pada Rajah 1.1, semua cabang suku Dusun Tindal tersebut ada kod kawasannya, kecuali Dusun Ranau, Paitan dan Mangahak. Menurut pandangan informan, kawasan Dusun Ranau adalah dalam kod 112, Paitan dalam kod 105 dan 112, dan Mangahak dalam kod 117. Suku Dusun Tindal merupakan etnik terbesar di Sabah. Pada awalnya suku ini berasal dari Kota Belud, kemudian mereka berhijrah ke kawasan-kawasan lain di Sabah.

Seterusnya, informan kedua mengatakan bahawa Dusun Tindal bermaksud 'orang yang tinggal di darat' dan 'orang yang suka berkebun'. Selain itu, Tindal bermaksud 'orang yang bercucuk tanam dan mengamalkan pertanian pindah, iaitu padi bukit'. Pada masa kini, suku Dusun Tindal sudah meninggalkan amalan pertanian pindah tetapi masih bercucuk tanam di kawasan tanah masingmasing. Ekoran penyebaran kawasan yang berbeza-beza, suku Dusun Tindal bertutur dialek kawasan masing-masing tetapi masih ada kefahaman menyilang antara sesama mereka semasa berkomunikasi. Selain itu, suku Dusun Tindal semakin berkembang melalui perkahwinan. Informan kedua ialah pengasas dan presiden Pertubuhan Tindal Bersatu Sabah. Menurutnya, terdapat lebih kurang 42 suku kaum Dusun di Sabah termasuk Dusun Tindal. Beliau telah memberikan satu gambar rajah (Rajah 1.2) berhubung pembahagian suku kaum Dusun yang terdapat di negeri Sabah.

Berdasarkan Rajah 1.2, Misompuru Doid Koubasanan (Perpaduan Melalui Kebudayaan), terdapat 4 suku kaum yang besar di Sabah, iaitu Dusun, Paitan, Rungus dan Murut. Kadazan merupakan suku di bawah keluarga kaum Dusun. Namun begitu, pada masa pemerintahan Tun Fuad Stephen sebagai Ketua Menteri Sabah dalam tahun 1970-an, Tun Fuad Stephen telah membahagikan suku kaum di Sabah ke dalam satu nama, iaitu Kadazan. Di bawah nama Kadazan inilah disimbiosiskan 4 suku kaum: Dusun, Murut, Rungus dan Paitan. Tujuan pembentukan suku kaum di bawah satu nama adalah untuk menyatukan kaum-kaum di negeri Sabah. Jika dilihat pada peta dalam Rajah 1.2, kaum Dusun di Sabah terdiri daripada 16 suku; Kuijau, Bisaya, Tatana, Lotud, Kimaragang, Tebilung, Garo, Gana, Tunawon, Kuriou, Sukang, Tangara, Tindal, Bundu, Sonsogon dan Liwan. Suku Dusun Ranau, Paitan dan Mangahak tidak tercatat di mana-mana kawasan dalam peta itu. Sewaktu penyelidik bertanyakan maksud 'Kadazan', James (2019) menjelaskan bahawa Kadazan bermakna 'orang yang tinggal berhampiran dengan bandar dan etnik asli dari kawasan Papar dan Penampang yang berdekatan dengan pekan'. Oleh sebab pemimpin terdahulu ingin membuat penyatuan kaum, Kadazan telah diambil sebagai satu suku yang mewakili semua suku kaum Dusun di negeri Sabah. 


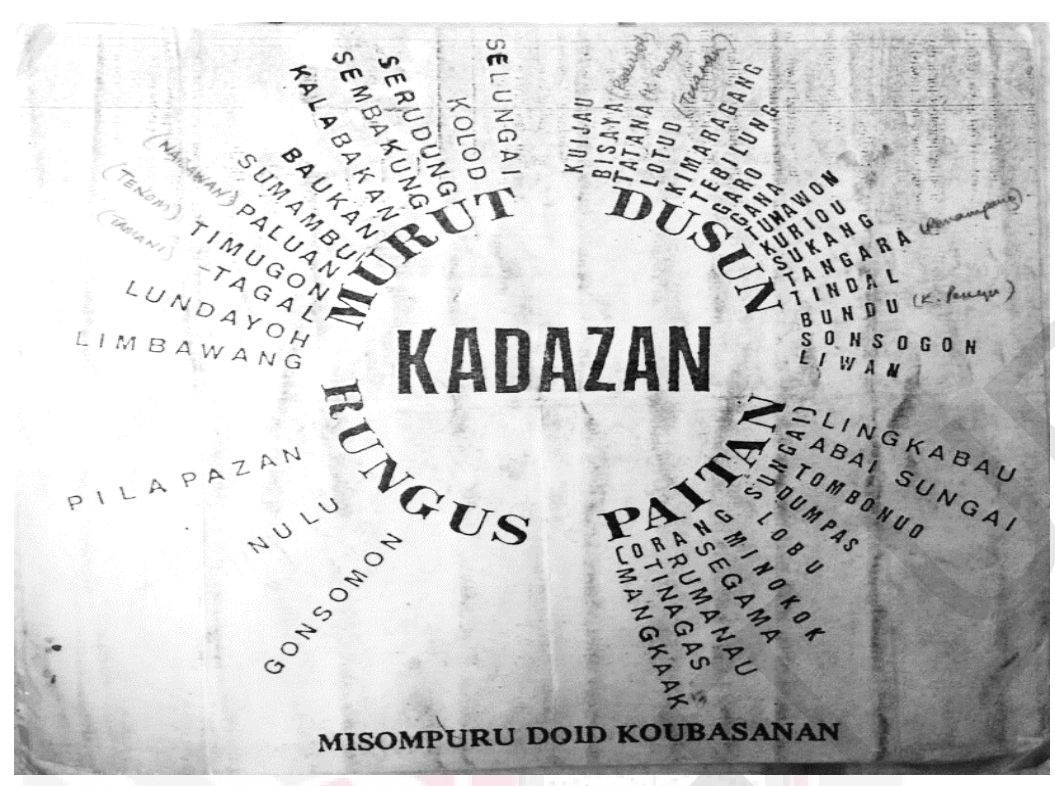

\section{Rajah 1.2: Pembahagian Suku kaum Dusun di Negeri Sabah} (Sumber : James Baga, 2019)

\section{Struktur Bahasa Dusun Tindal}

Struktur frasa bahasa Dusun Tindal berbeza daripada bahasa Melayu yang lazimnya mengandungi Subjek - Kata kerja - Objek (S - Kk - O). Binaan struktur frasa bahasa Dusun Tindal ialah Kata kerja - Subjek - Objek (Kk - S - O).

Contoh:

Monginum yau do waig (Bahasa Dusun Tindal)

Minum dia air

$\mathrm{Kk} \quad \mathrm{O} \quad \mathrm{S}$

Dia minum air (Bahasa Melayu)

$\mathrm{S} \quad \mathrm{Kk} \mathrm{O}$

Dalam subtajuk ini penyelidik menerangkan konstituen bahasa Dusun, yakni struktur frasa nama, ayat tanya $\mathrm{WH}$, ayat tanya Ya-Tidak, ayat nafi dan partikel nu 'apa'. Konstituen bahasa Dusun ternyata berbeza dengan bahasa Melayu baku. Perbezaan dua bahasa ini menyebabkan pemfosilan dalam bahasa antara pelajar suku Dusun Tindal.

i. Struktur frasa nama

$\mathrm{KN}+(\mathrm{do})$ + penerang

Cth.

guas (do) pioso

batang kelapa

= batang kelapa 
$\mathrm{KN}+$ demonstratif (do), demonstratif (i) $+\mathrm{KN}$

Cth.

buuk diti

buku ini

$=$ buku ini

$\mathrm{KBil}+\mathrm{KN}$

Ayat bukan kopula: Predikat Subjek

Ogumu piboroson id pogun Sabah.

Banyak bahasa di negeri Sabah.

= Banyak bahasa di negeri Sabah

KAdj. + KN

Alawa ilo hotel.

cantik itu hotel.

Mangakan yahe (do) mi guring (do) suab.

Makan kami mee goreng esok.

= Esok kami makan mee goreng.

ii. Ayat tanya WH

Kata tanya di pangkal ayat.

Nunu padagangon diolo hilo?

apa jual mereka di sana?

= Apakah yang mereka jual di sana?

iii. Ayat tanya Ya-Tidak

Boleh dibentuk dengan intonasi saja.

Madagang yolo kasai (do) takanon?

menjualmereka juga makanan?

= Adakah mereka juga menjual makanan?

Partikel (do) ialah kata nama yang 'dikenakan perbuatan'. Fungsi sintaksis kasus akusatif adalah untuk mengenal pasti objek langsung sesuatu tindakan, hasil yang diniatkan, matlamat sesuatu pergerakan, dan keluasan sesuatu tindakan.

iv. Ayat nafi

Okonko tulun isio do Malaysia, tulun isio do Jipun

Bukan orang dia Malaysia, orang dia Jepun

= Dia bukan orang Malaysia, dia orang Jepun.

Nga okon ko osomok mantad hiti tapi bukan lah dekat dari sini = Tetapi bukanlah dekat dari sini. 
Nga amu i Kasuga gumuli todo diri tapi tidak si Kasuga balik hari itu

= Tetapi si Kasuga tidak balik hari itu.

Awu. Aiso buuk hilo

Tidak. tiada buku sana

= Tidak. Di sana tiada buku.

v. Partikel nunu 'apa'

Mesti muncul di slot ketiga, tidak kira urutan relatif dengan KK

Nunu takanon nu?

Apa sedang makan awak

= Apa awak sedang makan?

Nunu nakan nu?

Apa telah makan awak

= Apa yang awak telah makan?

Nunu koubasan nu mangakan do kosuabon?

Apa biasa awak makan waktu pagi

= Apa yang biasa awak makan pada waktu pagi?'

Kedudukan kata ganti nama bentuk $\mathrm{O}$

Kata ganti nama bentuk $\mathrm{O}$ mesti muncul di slot kedua dari segi fonologi, bukannya dari segi struktur sintaksis.

Mantad oku Sandakan.

dari saya Sandakan.

= Saya dari Sandakan.

Partikel (do) sebagai penanda kasus genetif.

Tulun do Jipun yau.

Orang Jepun dia.

$=$ Dia Orang Jepun.

Okonko tulun isio do Malaysia, tulun isio do Jipun

Bukan orang dia Malaysia, orang dia Jepun

= Dia bukan orang Malaysia, dia orang Jepun.

Kasus genetif ialah kata nama yang mengubah kata nama yang lain. la sering menandakan kata nama yang memiliki kata nama yang lain. 


\section{Sistem Bahasa Antara (Interlanguage System)}

Istilah bahasa antara (interlanguage) pertama kali digunakan oleh Selinker pada tahun 1969. Dalam proses belajar bahasa sasaran, peserta didik mengalami tahap proses psikolinguistik sebelum mereka memperoleh bahasa sasaran. Prestasi bahasa pelajar yang tidak sempurna kerana belum mencapai kecekapan dalam bahasa sasaran mengandungi bentuk bahasa yang menyimpang daripada sistem bahasa sasaran. Tahap ini dipanggil bahasa antara (interlanguage).Bahasa antara adalah bebas, tidak berkaitan dengan bahasa pertama dan juga tidak berkaitan dengan bahasa sasaran, walaupun kadang-kadang menunjukkan pengaruh kedua-duanya. Apabila orang yang berpendidikan mengubah dan menghasilkan corak bahasa kerana aktiviti pembelajarannya, pengaruh bahasa pertama sering menyela. Aktiviti pembelajaran menghasilkan corak bahasa sasaran yang mengandungi elemen bahasa pertama.

Bahasa antara ialah sistem terpisah antara bahasa pertama dengan bahasa sasaran berdasarkan output yang dapat diamati, yang dihasilkan dari upaya pelajar untuk menghasilkan norma-norma bahasa pertama dan bahasa sasaran. Selinker (1972, ms. 215) merupakan pengkaji pertama yang menggunakan istilah ini. Menurutnya, penutur bahasa ibunda bukannya tiba-tiba menjadi penutur bahasa sasaran. Ini merupakan proses yang berkesinambungan, membuat dan menguji andaian bahasa pertama-bahasa sasaran dalam keadaan fikiran yang bingung antara pengetahuan bahasa yang sedia ada dengan struktur baharu seperti yang ditunjukkan dalam Rajah 1.3.

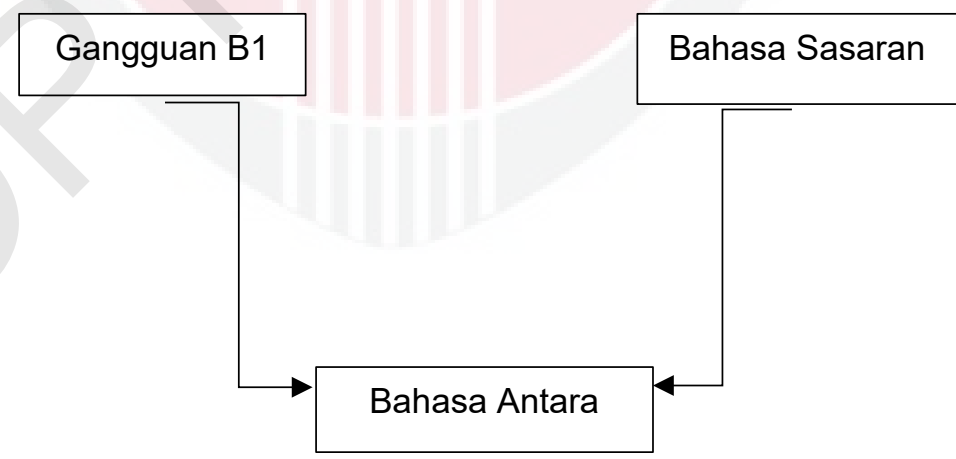

Rajah 1.3: Peralihan kecekapan dalam bahasa antara

(Sumber: Bohatala, 2018) 
Aplikasi Rajah 1.3. berdasarkan sumber Bohatala (2018) untuk kes penyelidikan ini ialah peralihan kecekapan dalam bahasa antara pelajar suku Dusun Tindal. Mereka belum menghampiri kecekapan bahasa seperti penutur asli bahasa Melayu baku. Mereka masih menerapkan peraturan bahasa ibunda (bahasa Dusun Tindal) dalam bahasa Melayu kerana tidak memahami batas peraturan antara bahasa Dusun Tindal dengan bahasa Melayu baku. Dalam pemikiran pelajar suku Dusun Tindal, peraturan yang mereka gunakan adalah logik, misalnya pelajar menghasilkan ayat bahasa Melayu baku yang memperlihatkan kewujudan struktur ayat bahasa Dusun Tindal.

\section{BM Baku}

1. Kuih itu sudah beku

\section{Bahasa Antara}

Karas suda itu kuih Nokodou no ilo kuui

Penerangan terbaharu tentang istilah 'bahasa antara' ditemui dalam Gang Dong (2013, ms. 42). Menurutnya, proses pemindahan bahasa ibunda yang diandaikan oleh Selinker berlaku sewaktu pelajar melaksanakan tugasan bahasa sasaran. Hala tuju perkembangan bahasa sasaran pelajar sama seperti penara (plateau) yang menggambarkan kesilapan dan prestasi sebenar pelajar. Bahasa antara pelajar mengandungi kesilapan pemindahan daripada bahasa pertama (bahasa ibunda) seperti terlebih generalisasi dalam contoh ayat berikut yang dihasilkan oleh pelajar suku Dusun Tindal.

2. Hari sudah menginjak petang. (terlebih generalisasi)

Perkataan menginjak dalam ayat tersebut sepatutnya ditulis 'beransur'.

Terlebih generalisasi peraturan bahasa sasaran menunjukkan bukti pelajar telah menguasai peraturan umum, tetapi masih tidak mengetahui pengecualian yang ada pada peraturan bahasa sasaran. Gang Dong (2013, ms. 43) mengatakan bahawa pelajar bahasa kedua menggunakan penanda kala lampau -ed untuk semua kata kerja sama ada secara tetap atau tidak teratur; walked, wanted, hugged, laughed, hitted, gived, goed. Kesalahan terlebih generalisasi menunjukkan pelajar mengetahui peraturan bahasa sasaran, tetapi masih ada yang belum dipelajari.

Dalam hipotesis yang dikemukakan oleh Selinker, bahasa antara mempunyai tiga sifat, iaitu, i) bahasa antara mengandungi fosil; ii) bahasa antara menunjukkan ciri pemindahan bahasa pertama; iii) bahasa antara menunjukkan ciri kebolehubahan. Sifat pertama biasa terjadi dalam sistem bahasa antara. Sifat kedua tidak semestinya ada dalam bahasa antara. Bagi sifat ketiga, terdapat pendapat yang berbeza sama ada kebolehubahan ialah milik sistem bahasa antara atau penggunaan bahasa antara (Gang Dong, 2013, ms. 43). 


\section{Pernyataan Masalah}

Bahasa antara didefinisikan sebagai sistem bahasa yang dinamik yang dihasilkan oleh pelajar bahasa kedua (Saric, 2016: ms 242). Pilihan bahasa di setiap tahap kontinum bahasa antara mempunyai kesan ke atas perkembangan bahasa kedua pelajar. Hal ini demikian kerana bahasa antara pelajar menjadi stabil jika pelajar memilih sejumlah besar item struktur bahasa yang tidak betul (Saric, 2016, ms. 247). Individu cenderung untuk memindahkan bentuk dan makna dari bahasa ibundanya kepada bahasa sasaran ketika cuba berbicara dan memahami bahasa yang diamalkan oleh penutur natif (Sidupa, 2018, ms. 52). Pelajar suku Dusun Tindal yang dikaji biasanya menggunakan linguistik bahasa ibunda semasa belajar bahasa Melayu baku sebagai bahasa kedua.

Secara semula jadi, dalam masa interim, pelajar membina sistem linguistik yang berbeza daripada bahasa pertama dan juga bahasa sasaran. Inilah yang dipanggil bahasa antara (CarolineMwendwa, 2017: 42). Selinker ialah ahli bahasa yang pertama mengemukakan idea bahasa aantara dalam kertas kerjanya yang bertajuk Interlanguage pada tahun 1972. Dari pemerhatiannya, beliau mengatakan sebanyak 95\% pelajar B2 gagal mencapai tahap kompetensi yang sama dengan penutur bahasa pertama. Pelajar bahasa kedua cenderung untuk mengekalkan bahasa antara yang produktif, tidak kira berapa umur pelajar atau jumlah pengajaran bahasa kedua yang telah diterima oleh pelajar.

Sewaktu proses bahasa antara atau 'peralihan kecekapan bahasa', beberapa isu muncul akibat pemindahan bahasa pertama ke dalam bahasa sasaran. Pemindahan negatif dapat menyebabkan berlakunya pelbagai kesilapan kerana salah faham dan salah tanggapan pelajar semasa cuba menggunakan bahasa sasaran (Aras, 2017, ms 34). Bahasa berbeza antara satu sama lain. Salah satu faktor yang dikaitkan dengan perbezaan ini ialah linguistik silang budaya, yang mana setiap bahasa mempunyai budaya sendiri. Ini memberi kesan kepada pelajar suku Dusun Tindal semasa menggunakan bahasa mereka sendiri untuk dimasukkan ke dalam bahasa Melayu baku. Sebagai contoh, sewaktu menggunakan bahasa Melayu baku, kebanyakan pelajar suku Dusun Tindal tidak melihat perbezaan makna antara frasa 'cepat betul' dengan kata 'pantas'; kata 'berjalan' dengan 'berlalu'. Kesilapan penggunaan frasa dan kata tersebut dilakukan berulang kali melangkaui batas waktu. Ayat 1 yang berikut sering ditulis atau dituturkan oleh kebanyakan pelajar suku Dusun Tindal.

Ayat 1: Cepat betul masa berjalan (Masa berlalu dengan pantas)

Ayat 2: $\quad$ Kau buanglah perangai buruk itu (Awak buanglah perangai buruk itu)

Dua kesilapan dapat dikesan dalam Ayat 1, iaitu penggunaan kata 'berjalan' dan frasa 'cepat betul' merupakan Terlebih Generalisasi (Overgeneralization), iaitu salah satu bentuk bahasa antara. Ayat 1 mengandungi struktur ayat bahasa Dusun Tindal dengan pendepanan kata kerja sebelum kata keterangan. Kata 
'Kau' dalam Ayat 2 lumrah dalam pertuturan orang Sabah. Kata yang lebih sesuai ialah 'Awak'.

Pembetulan kesilapan kosa kata mengambil masa dan sukar dibetulkan selagi tiada kesedaran di pihak pelajar atau jika markah tugasan/ujian pelajar tidak terjejas dengan teruk. Daripada hasil kajian Qian dan Xiao (2010, ms. 180), penyelidik mengetahui hanya $5 \%$ pelajar bahasa kedua mencapai kompetensi bahasa sasaran manakala $95 \%$ menunjukkan kompetensi yang berbeza-beza. Hal ini disebabkan penara sementara dalam bahasa antara dalam kalangan $5 \%$ pelajar bahasa kedua. Pembelajaran bahasa kedua ialah pembelajaran sejenis kemahiran. Penara sementara dikesan dengan meneliti graf kemajuan bahasa pelajar yang mendatar seakan-akan plateau. Dengan kata lain, kemampuan awal bahasa kedua memperlihatkan peningkatan linear, tetapi pada peringkat tertentu tidak stabil, seterusnya graf menunjukkan pencapaian yang mendatar, bahkan ada yang dalam keadaan menurun. Penyelidik menemui bentuk penara sementara dalam penulisan karangan bahasa Melayu baku pelajar semasa penyelidik menjalankan kajian rintis terhadap 30 pelajar suku Dusun Tindal.

Belajar bahasa bukanlah proses yang sentiasa lancar. Pelajar suku Dusun Tindal mengalami lonjakan dan penurunan prestasi bahasa. Pada peringkat awal pembelajaran, mereka jelas melihat kemajuan pembelajaran mereka. Mereka mengatasi semua rintangan dalam belajar, bersemangat dan berjaya. Bagaimanapun, apabila sampai tahap pertengahan pembelajaran bahasa, mereka perlu menyatukan dan mengaplikasikan pengetahuan yang sedia ada. Mereka tersekat di penara dalam pembelajaran. Keadaan ini membuat mereka lebih sukar untuk mengetahui apa yang harus dicapai dan mengenali keberhasilan pengetahuan.

Penyelidik berpendapat pembelajaran menerusi hubungan dengan rakan-rakan melahirkan bahasa idiosinkratik (kebiasaan) yang terdapat dalam susunan bahasa antara pelajar suku Dusun Tindal. Pandangan yang sama pernah dikemukakan oleh Wei (2008, ms. 129) berkaitan dengan pelajar jalanan dan pelajar sekolah. Menurutnya, bentuk bahasa antara sering berlaku dalam kalangan pelajar jalanan yang mempunyai peluang yang luas untuk berkomunikasi dengan sesiapa walaupun pola leksikal dan sintaksis yang mereka gunakan tidak betul. Kesudahannya, kesilapan bahasa pelajar jalanan menjadi sistematik dan hampir mustahil untuk dibendung. Bahasa pelajar jalanan tidak pernah dibetulkan, mereka juga tidak berhasrat untuk membuat pembetulan.

Pelajar suku Dusun Tindal sebagai pelajar bahasa kedua di sekolah-sekolah kerajaan tidak terkecuali daripada terkandas dalam pelbagai penara perkembangan bahasa. Pelajar-pelajar ini telah dipengaruhi pengalaman bahasa terdahulu seperti ciri tidak formal pembelajaran jalanan dalam budaya sasaran, yang kemudian menghalang kemajuan bahasa mereka sewaktu menyertai pengajaran formal di dalam bilik darjah. 
Dalam proses pembelajaran bahasa kedua, fosilisasi akibat penggunaan strategi pembelajaran yang salah adalah yang paling biasa ditemui. Menurut Sims (1989, ms. 65), strategi pembelajaran yang tidak sesuai atau tidak berjaya dilaksanakan boleh menyebabkan beberapa ciri fosilisasi (fonologi, morfologi, sintaksis, leksikal, psikolinguistik, atau sosiobudaya) di sepanjang kontinum bahasa antara.

Strategi pembelajaran merujuk bukan sahaja keseluruhan strategi yang ada tetapi juga kaedah-kaedah eksplisit yang digunakan oleh pelajar dalam proses pembelajaran bahasa kedua. Penggunaan strategi pembelajaran yang sesuai membantu proses input bahasa antara, seterusnya dapat meningkatkan kualiti pembelajaran bahasa kedua. Akan tetapi, terdapat pelajar suku Dusun Tindal beralih kepada strategi pembelajaran seperti terlebih generalisasi, pemudahan, aplikasi peraturan yang tidak lengkap dan pengetahuan ayat penyata bahasa kedua yang tidak memadai. Penggunaan berulang strategi yang tidak berjaya akan membantutkan kemajuan kompetensi bahasa Melayu pelajar suku Dusun Tindal.

Pelajar suku Dusun Tindal cenderung menggunakan peraturan tatabahasa bahasa Melayu yang mudah-mudah seperti kata sandang (si adik, si anu, jadi...) dan bentuk jamak seperti jalan-jalan, diam-diam, makan-makan, ampai-ampai dan lain-lain seumpamanya dalam ayat. Keadaan ini mencerminkan kesan bahasa kolokial dalam kehidupan seharian pelajar. Sekiranya pelajar berterusan mengabaikan ketepatan bahasa sewaktu berkomunikasi, kecekapan bahasa Melayu baku pelajar tidak bertambah.

Terlebih generalisasi melibatkan penggunaan pengetahuan bahasa kedua yang sedia ada pada pelajar yang diperluaskan dalam bentuk bahasa antara (Ellis, 2002). Dalam kes pelajar suku Dusun Tindal, pelajar menggunakan peraturan tatabahasa tanpa had penyesuaian. Pelajar tidak tahu had peraturan, termasuk had semantik sesuatu leksis atau item linguistik lain. Contoh terlebih generalisasi yang berikut dipetik daripada Noor Aina dan Patarai (2010).

Ayat 3: $\quad$ Saya baca buku cerita itu supaya saya pandai sebab itulah saya baca buku.

(Saya membaca buku cerita itu untuk menambah ilmu pengetahuan)

Tanpa pengajaran dan pembetulan kesilapan seperti Ayat 3, terlebih generalisasi ayat kekal berterusan.

Masalah sikap yang sering dihadapi oleh masyarakat suku Dusun Tindal di Tenghilan, Tuaran, Sabah ialah penutur dalam kalangan generasi muda menggunakan bahasa yang berbeza daripada bahasa asli yang dituturkan oleh generasi tua. Hal ini menghasilkan perubahan yang sangat cepat menuju kepada bahasa yang terancam punah. Jika percakapan penutur generasi muda 
dianggap oleh penutur generasi tua sebagai tidak memadai kerana sikap mereka yang mementingkan kesempurnaan bahasa, maka penutur golongan muda mungkin berputus asa untuk terus bertutur dalam bahasa ibunda. Pengamatan ini dibuat oleh Bradley (2002) dalam kajiannya tentang bahasa kaum Bisu dan Gong di Thailand. Bradley percaya jika versi 'separuh mahir' dalam bahasa ibunda diterima dalam komuniti, versi ini dapat bertahan atau perubahan mungkin berterusan. Pengamatannya menunjukkan jenis perubahan yang demikian telah dipermudahkan dan telah bersatu dengan struktur bahasa pengganti, di mana semua atau sebahagian besar penutur cenderung dwibahasa atau multibahasa.

\section{Objektif Kajian}

Sebanyak tiga objektif telah dikenal pasti untuk menyempurnakan penyelidikan ini. Setiap objektif saling melengkapi, yakni tanpa salah satu daripadanya, isi tesis ini tidak sempurna dalam menghubungkaitkan bahasa antara dalam penulisan karangan bahasa Melayu baku pelajar suku Dusun Tindal di negeri Sabah. Objektif kajian diperturunkan seperti yang berikut:

1. Mengenal pasti faktor yang mempengaruhi kewujudan bahasa antara pelajar suku Dusun Tindal.

2. Menganalisis bentuk bahasa antara dalam penulisan karangan Bahasa Melayu pelajar suku Dusun Tindal yang dikaji.

3. Merumus tahap bahasa antara pelajar suku Dusun Tindal yang dikaji.

\section{Persoalan Kajian}

1. Apakah faktor-faktor yang mempengaruhi penggunaan bahasa pelajar suku Dusun Tindal secara dominan?

2. Sejauh manakah bentuk bahasa antara dalam penulisan karangan bahasa Melayu pelajar suku Dusun Tindal berkaitan dengan sebabmusabab?

3. Bagaimanakah untuk membina Kontinum Bahasa Antara dalam pembelajaran bahasa Melayu sebagai bahasa kedua oleh pelajar suku Dusun Tindal? 


\section{Hipotesis Kajian}

Penyelidik telah menetapkan empat hipotesis kajian untuk tesis ini. Berdasarkan dapatan kajian di Bab 4, barulah penyelidik memutuskan sama ada menerima atau menolak hipotesis kajian.

Hipotesis 1: Transmisi bahasa ibunda daripada ibu bapa (generasi tua) kepada pelajar (generasi muda) adalah pada tahap selamat.

Hipotesis 2: $\quad$ Trend dalam domain bahasa ibunda pelajar yang sedia ada semakin menyusut.

Hipotesis 3: Bahasa antara dalam penulisan karangan bahasa Melayu baku pelajar adalah bersifat sementara.

Hipotesis 4: $\quad$ Pengetahuan kosa kata dalam Kontinum Bahasa Antara

pelajar adalah lebih tinggi daripada pengetahuan ayat.

\section{Kepentingan Kajian}

Teori Bahasa Antara (Selinker, 1972; 1974) sesuai untuk bidang pembelajaran B2 kerana fokus pendekatan pada bahasa antara yang berkaitan dengan percubaan pelajar bahasa kedua atau bahasa sasaran mengawal pembelajaran secara sedar. Pelajar dilihat sebagai peserta aktif yang mempunyai keupayaan untuk melepasi ketegaran bahasa antara. Teori Bahasa Antara menerima kesilapan bahasa sebagai sebahagian daripada proses pembelajaran, dengan demikian mengurangkan tekanan di pihak guru dan memudahkan guru bahasa menentukan apa yang diketahui oleh pelajar suku Dusun Tindal pada suatu masa tertentu serta apa yang harus diajar.

Matlamat akhir penyelidikan bahasa kedua adalah untuk memahami apa yang diperoleh (dan apa yang tidak diperoleh) dan mekanisme yang merungkai pengetahuan B2 (Gass, 1998, ms. 198). Salah satu perkara penting dalam teori pembelajaran bahasa kedua ialah bentuk linguistik dalam bahasa antara menentukan peralihan kecekapan bahasa antara pelajar dan sebagai penanda aras pengetahuan kosa kata dan ayat bahasa Melayu baku pelajar suku Dusun Tindal. Oleh sebab itu, adalah penting untuk mengenal pasti faktor yang mempengaruhi kewujudan bahasa antara pelajar suku Dusun Tindal.

Identifikasi bahasa antara dalam kalangan pelajar suku Dusun Tindal juga penting agar membolehkan guru membimbing pelajar dengan kaedah pengajaran yang bersesuaian. Identifikasi bahasa antara yang relevan boleh ditetapkan berdasarkan kemajuan bahasa yang disyorkan oleh Saville (2006, ms. 41), yang merangkumi perkataan, frasa dan ayat bahasa ibunda juga bahasa sasaran yang dihasilkan oleh pelajar. Tiga set pernyataan ini dijadikan 
kerangka untuk menentukan struktur permukaan bahasa antara pelajar suku Dusun Tindal.

Seterusnya, penyelidik berhasrat untuk mengenal pasti penara bahasa pelajar suku Dusun Tindal dalam dua cara. Pertama, menilai hasil ujian karangan yang mengukur kecekapan dan pencapaian dalam bahasa yang mereka sedang belajar. Kedua, meneliti pengetahuan kos kata pelajar dengan menggunakan inventori versi bahasa Dusun Tindal dan versi bahasa Melayu untuk terjemahan sebagai strategi pembelajaran. Idea ini dipadankan daripada kajian Al-Musawi (2014). Penggunaan dua cara ini dijangka memberi maklumat tentang pelajar yang berjaya atau tidak berjaya melepasi penara bahasa antara.

Pengurangan pemindahan negatif bahasa pertama agak jelas pada peringkat permulaan pelajar suku Dusun Tindal belajar bahasa Melayu baku kerana pengetahuan bahasa kedua mereka agak terhad. Penyelidik melihat adanya kepentingan untuk meneliti takat kebergantungan pelajar pada bahasa ibunda yang membentuk sistem bahasa antara kerana pemindahan negatif. Pemindahan bahasa ialah salah satu konsep yang paling penting dalam amalan dan teori pendidikan. Malah, prinsip pemindahan bahasa merujuk kepada hipotesis bahawa bahasa pertama mempengaruhi bahasa sasaran. Fenomena pemindahan bahasa berlaku semasa memperoleh bahasa baharu disebabkan sebutan, tatabahasa atau aspek lain dari bahasa pertama pelajar. Apabila pelajar cuba berkomunikasi dalam bahasa asing atau kedua, mereka sering memindahkan beberapa elemen bahasa ibunda mereka ke corak bahasa sasaran dalam penulisan (Aras, 2017, ms. 34). Penelitian terhadap bahasa ibunda pelajar menawarkan beberapa input bahasa sasaran. Hanya melalui input bahasa sasaran yang banyak, pemindahan negatif bahasa ibunda dapat dikurangkan. Input bahasa yang mencukupi ialah kaedah yang berkesan untuk mengatasi pemindahan negatif bahasa ibunda.

Adaptasi strategi pembelajaran yang betul mampu mengurangkan bahasa antara dalam karangan bahasa Melayu pelajar suku Dusun Tindal. Menurut Krashen (2003, ms. 29), beberapa kajian telah dijalankan berdasarkan andaian bahawa terdapat strategi pembelajaran yang 'baik'. Pengalaman belajar bahasa kedua pelajar yang berjaya sangat bernilai untuk dikongsi dengan pelajar lain. Hasil temu bual berstruktur antara penyelidik dengan guru-guru bahasa penting untuk mendapatkan maklumat tentang strategi pembelajaran yang 'baik' yang mereka gunakan dalam bilik darjah. Maklumat awal yang diperoleh daripada kajian rintis menemui tiga faktor yang penting.

Pertama, pelajar yang berjaya kelihatan menggunakan strategi pembelajaran lebih kerap berbanding dengan yang kurang berjaya. Sebagai contoh, pelajar suku Dusun Tindal menggunakan strategi hafalan semasa belajar perbendaharaan kata dan kerap menggunakan kamus. Kedua, pelajar yang berjaya memberi perhatian pada bentuk dan makna bahasa. Pelajar bahasa yang baik kelihatan seperti dapat menukar fokus perhatian mereka ketika sedang melakukan tugasan. Dengan kata lain, mereka cenderung membuat 
perbandingan silang bahasa yang berkesan, menganalisis bahasa sasaran, dan menggunakan buku rujukan. Ketiga, sesuatu strategi pembelajaran menyumbangkan aspek kecekapan bahasa kedua yang berbeza, yakni strategi yang melibatkan latihan secara formal mampu mengembangkan kecekapan linguistik. Strategi yang melibatkan latihan fungsian menambah kecekapan komunikatif. Pemilihan strategi pembelajaran bahasa kedua secara fleksibel adalah penting dalam melaksanakan tugasan bahasa. Berdasarkan amalan pengajaran dan pembelajaran bahasa Melayu pelajar suku Dusun Tindal di Tenghilan Tuaran, Sabah; kandungan tesis mengemukakan hasil penyelidikan tentang sebab-musabab bahasa antara dalam pembelajaran bahasa Melayu baku serta menawarkan beberapa strategi yang sesuai untuk mengatasi halangan kompetensi dalam penulisan karangan dan pengetahuan kosa kata bahasa Melayu baku.

Penentuan pemilihan bahasa membolehkan satu kumpulan penutur dibezakan daripada yang lain (Edwards, 2009, ms. 21). Pemilihan bahasa yang khusus dalam kalangan ibu bapa pelajar suku Dusun Tindal adalah sebagai satu cara untuk penyelidik mengetahui tahap transmisi bahasa antara generasi tua dengan generasi muda. Di samping itu, penyelidik dapat menentukan trend dalam domain bahasa ibunda yang sedia ada. Trend pilihan pelajar adalah penting kerana sikap pelajar suku Dusun Tindal terhadap bahasa ibunda sentiasa mengalami proses perubahan mengikut arus masa dan dinamik masyarakat, menggabungkan unsur-unsur baharu dan meninggalkan yang lama. Sikap mereka terhadap bahasa ibunda menerangkan pandangan dunia mereka secara literal yang membentuk cara pemikiran dan ekspresi yang unik (Riley, 2007, ms. 9). Dalam situasi geo budaya sedemikian rupa, kecenderungan untuk menggunakan bahasa lain selain daripada bahasa ibunda dalam masyarakat budaya induk tidak dapat dielakkan. Kecenderungan ini lebih ketara lagi lantaran wujudnya tekanan ekonomi dan politik yang dikuasai oleh kumpulan etnik lain yang lebih besar. Tekanan-tekanan ini boleh menyebabkan berlakunya perubahan dan peralihan bahasa. Ini sekali gus akan mengubah identiti masyarakat suku Dusun Tindal itu sendiri.

\section{Skop Kajian}

Skop kajian ini merangkumi kewujudan faktor, bentuk dan tahap bahasa antara dalam penulisan Bahasa Melayu Baku sebagai bahasa kedua dalam kalangan pelajar suku Dusun Tindal yang dikaji. Teori Bahasa Antara (Selinker, 1972; 1974) dimanfaatkan untuk meneliti penara bahasa (language plateau) dan kontinum bahasa antara para pelajar. Selain itu, Taksonomi Faktor Penyebab Pemfosilan (Han, 2003) diaplikasikan untuk membincangkan kewujudan itemitem bahasa antara dalam penulisan karangan BM baku pelajar SDT. Kaedah kajian kes dilaksanakan di Sekolah Menengah Kebangsaan Tenghilan, Tuaran, Sabah. Sebanyak 69 pelajar suku Dusun Tindal yang belajar dalam tingkatan empat di sekolah tersebut dipilih menyertai penyelidikan ini. Penyelidik turut melaksanakan temu bual bersemuka dengan 12 orang guru yang mengajar mata pelajaran Bahasa Melayu. Temu bual bersemuka ke atas 2 orang informan dilaksanakan untuk mendapatkan maklumat etnologi suku Dusun Tindal di 
Sabah. Mereka ialah seorang penduduk warga emas dan seorang lagi ialah pengasas dan presiden Pertubuhan Tindal Bersatu Sabah. Penyelidikan bermula pada 21 September 2016 hingga 27 Mac 2019. Agenda penyelidikan ialah kajian rintis, kajian kes, temu bual bersemuka dengan para guru, akhirnya temu bual dengan informan.

\section{Definisi Operasional}

Definisi operasional digunakan untuk memberi pemahaman tentang pemboleh ubah aktiviti kajian yang perlu diukur oleh penyelidik. Definisi operasional ialah jambatan antara tahap konseptual teori dengan tahap kajian yang empirikal. Penyelidik menggunakan dua definisi operasional, iaitu bahasa antara dan pelajar suku Dusun Tindal.

\section{Bahasa Antara}

Istilah Interlanguage (bahasa antara) pertama kali diperkenalkan oleh Selinker (1972 \& 1974) yang menyebutnya sebagai pengetahuan sistematik bahasa kedua (B2) yang bebas daripada bahasa pertama (B1) dan bahasa kedua (B2). Bahasa antara ialah jenis bahasa yang boleh dihasilkan oleh pelajar bahasa asing atau B2 yang sedang dalam proses memperoleh atau mempelajari bahasa baharu. Dalam perspektif kognitif, bahasa antara merujuk kepada pemisahan sistem B2 pelajar, sistem yang merangkumi status struktur antara bahasa natif dan bahasa sasaran. lanya mencerminkan percubaan pelajar B2 dalam membina sebuah sistem linguistik yang secara perlahan dan mendalam mendekati sistem bahasa sasaran (Fauziati, 2011). Definisi terbaharu ialah sistem bahasa yang dinamik yang dihasilkan oleh pelajar bahasa kedua (Saric, 2016, ms 242).

Bahasa antara tidak dipandang sebagai proses pembelajaran bahasa kedua yang dipengaruhi oleh B1 atau B2. Dalam erti kata lain, ia bukan sistem B1 atau sistem B2 atau bahasa sasaran, tetapi sebaliknya, sebagai sistem linguistik yang wujud secara bebas. Bahasa antara didapati pada pengetahuan pelajar B2 yang sudah ada dalam bahasa baharu yang mereka cuba belajar. Selinker (1972) mencadangkan bahawa bahasa antara, sebagai proses peralihan antara B1 dan B2, boleh dilihat dan diterokai dalam bahasa pelajar. Selinker menganggap bahasa antara sebagai "dialek yang berkongsi peraturan dua bahasa" ( dalam Corder, 1981: 17). Menurutnya, tanggapan bahasa antara digambarkan dalam Rajah 1.4. Dalam Rajah ini Bahasa A mewakili bahasa pertama (B1) pelajar. 


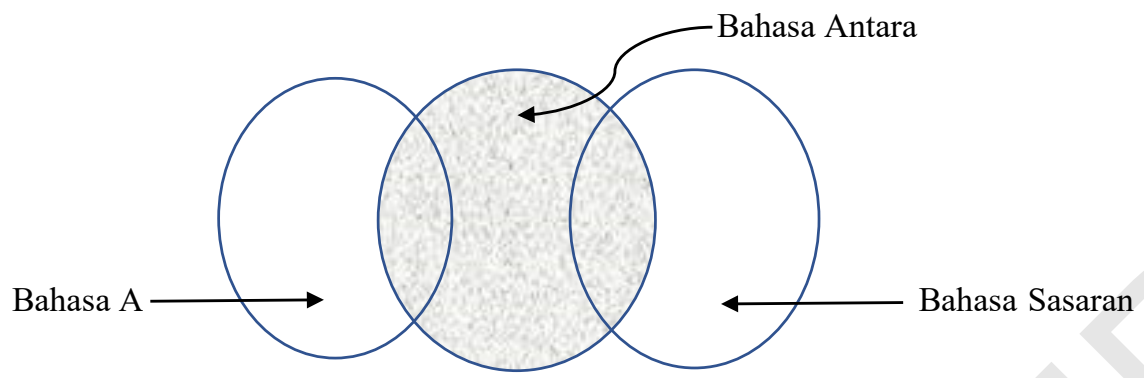

Rajah 1.4: Tanggapan tentang Bahasa Antara

(Sumber: Mohammad Hamad, 2015: 124)

Pelajar suku Dusun Tindal yang dikaji belum mahir menggunakan bahasa Melayu baku. Penyelidik menjelaskan perkongsian peraturan dua bahasa dalam penulisan karangan bahasa Melayu pelajar, iaitu:

i. Penggunaan bahasa ibunda (bahasa A) untuk menyampaikan mesej dalam bahasa sasaran (bahasa Melayu baku).

ii. Penggunaan bahasa Melayu baku untuk menyampaikan mesej dalam bahasa sasaran.

Penyelidik mentakrifkan bahasa antara sebagai ketegaran struktur bukan bahasa sasaran. Ketegaran struktur bukan bahasa sasaran terdiri daripada itemitem linguistik, peraturan, dan sub-sistem bahasa Dusun Tindal yang fosil dalam penulisan karangan bahasa Melayu baku. Kewujudan bahasa antara dalam penulisan karangan menunjukkan ciri ketegaran jangka panjang merangkumi bentuk bahasa antara yang terdiri daripada 6 proses berikut:

i. Pemindahan bahasa (Language transfer)

ii. Pemindahan latihan (Transfer of training)

iii. Strategi pembelajaran dan komunikasi (Strategies of learning and communication)

iv. Pemudahan (Simplification)

v. Terlebih generalisasi (Overgeneralization)

vi. Balik asal (Backsliding)

Selain itu, penyelidik akan menghasilkan graf penara bahasa (sementara atau jangka panjang) dan keluk pembelajaran bentuk $U$ sebagai produk bahasa antara. Penara bahasa dan keluk pembelajaran bentuk $U$ dihasilkan daripada data struktur bukan bahasa sasaran dalam bahasa antara pelajar suku Dusun Tindal yang tidak kompeten dalam bahasa Melayu baku. 
Sehubungan itu, data yang penyelidik persembahkan lebih banyak mengenai perbezaan struktur bahasa ibunda (bahasa Dusun Tindal) daripada bahasa sasaran (bahasa Melayu baku), yang mana pelajar cenderung keliru. Dengan itu membawa kepada kewujudan bahasa antara.

\section{Pelajar Suku Dusun Tindal}

Pelajar suku Dusun Tindal dalam kajian ini bermastautin di Tenghilan, Tuaran, Sabah. Mereka menuntut dalam tingkatan empat di Sekolah Menengah Kebangsaan Tenghilan, Tuaran, Sabah. Kumpulan remaja ini bertutur menggunakan bahasa ibunda, dialek Melayu Sabah dan bahasa Inggeris. Terdapat juga remaja yang menggunakan bahasa campuran kerana ibu bapa mereka kahwin campur dengan etnik lain di Sabah. 


\section{BIBLIOGRAFI}

Adista Nur Primantari dan Dewa Putu Wijana (2017). Tindak Tutur Meminta oleh Pembelajar BIPA Dari Korea: Kajian Pragmatik Bahasa Antara. Jurnal Penelitian Humaniora, 18(1): 27-40.

Al-Musawi, N. M. (2014). Strategic use of translation in learning English as a Foreign Language (EFL) among Bahrain university students. Comprehensive Psychology, 3(4): 2-10.

Alhamadi, N.S. (2015). Language Transfer errors in speaking among Saudi Arabia students; a comparative study between Students in Saudi Arabia and Students in the UK. Tesis Ph.D. United Kingdom: School of Languages, Cultures and Societies, University of Leeds.

Ahmad Mahdzan Ayob. (1993). Kaedah Penyelidikan Sosioekonomi. Kuala Lumpur: Dewan Bahasa dan Pustaka.

Ananda Kumar Palaniappan. (2009). Penyelidikan dan SPSS (PASW). Pearson. Petaling, Selangor. Malaysia.

Andrea, F. S. (2018). Challenging Fossilization: The Role of Motivation in Second Language Acquisition. BA dissertation. University of Autonoma de Barcelona.

Aras Abdalkarim Amin. (2017). Linguistic Analysis of the Phenomenon of Language Transfer. IOSR Journal Of Humanities And Social Science, 22 (4): 32-35.

Bohatala (2018). Interlanguage. Retrieved from https://bohatala.com/interlanguage-with-example/

Boyce, C. \& Neale, P. (2006). Conducting In- Depth Interviews: A Guide for Designing and Conducting In Depth Interviews for Evaluation Output. Massachusetts: Pathfinder International.

Bradley, D. (2002). Language attitudes: The key factor in language maintenance. In D. Bradley \& M. Bradley (Eds.), Language endangerment and language maintenance (pp.1-10). London: Routledge Curzon.

Brenzinger, M., Dwyer, M.A., de Graaf, T., Grinevald, C., Krauss, M, \& Miyaoka, O. (2003). Language Vitality and Endangerment. Paris: UNESCO Ad Hoc Expert Group on Endangered Languages.

Brown, H. D. (1980). 'The optimal distance model of second language acquisition'. TESOL Quarterly 14: 157-64. 
Brown, H. D. (1994). Principles of Language Learning and Teaching. (3rd edition.) Englewood CL1ffs, NJ: Prentice Hall.

CarolineMwendwa Muriungi. (2017). Interlanguage Strategy of Overgeneralisation used by Primary School Learners of English in MirigaMeru West Division Meru County. IOSR Journal Of Humanities And Social Science, 22 (12): 42-46.

Cheong Shaw Mei (2009). Realiti Perubahan Bahasa dalam Kelompok Sosial Pelajar KadazanDusun di Sabah. Tesis Master. Fakulti Bahasa Moden dan Komunikasi, Serdang, Selangor: Universiti Putra Malaysia.

Chong Shin, Hendrikus Mangku dan James T. Collins. (2018). Pemilihan Bahasa Komuniti Penan Muslim di Sarawak. GEMA Online ${ }^{\circledR}$ Journal of Language Studies, 18(4): 61-80.

Chua Yan Piaw. (2006). Kaedah Penyelidikan Buku 1. MC Graw Hill Education. Sdn. Bhd.

Collins, K.T. and Downes, L. W. (1973). Key words in education. USA: Longman.

Donald E. Polkinghorne. (2005). Language and Meaning: Data Collection In Qualitative Research. Journal of Counseling Psychology, 52(2):137145.

Eddine, A. N. (2012). Interlanguage prepositions: an analysis of French learners' productions in L2 English. PhD Thesis. France: Linguistics. Université de Grenoble.

Edwards, J. (2009). Language and identity: key topics in sociolinguistics. Cambridge: Cambridge University Press.

Ellis, R. (1985). Understanding Second Language Acquisition. Oxford: Oxford University Press.

Ellis, R. (2000). Understanding Second Language Acquisition. Shanghai: Shanghai Foreign Language education press.

Ellis, R. (2012). The Study of Second Language Acquisition. Oxford: Oxford University Press.

Endang Fauziati. (2011). Interlanguage and error fossilization: a study of Indonesian students learning English as a foreign language. Indonesian Journal of Applied Linguistics, 1(1): 25-40.

Farshad Maghnati, Kwek Choon Ling dan Amir Nasermoadeli. (2012). Exploring the Relationship between Experiential Marketing and Experiential Value in the Smartphone Industry. International Business Research, 5(11): 169-177. 
Fatin Rabiha Abdul Kadir dan Zaitul Azma Zainon Hamzah. (2017). Bahasa Antara dalam Komunikasi Lisan Penutur Melayu dan Penutur Bukan Melayu. International Journal of Language Education and Applied Linguistics, 7: 1-16.

Fauziati, E. (2011). Interlanguage and error fossilization: A study of Indonesian students learning English as a foreign language. Indonesian Journal of Applied Linguistics, 1(1), 23-38.

Foley, B. (2018). Purposive Sampling 101. What is purposive sampling? Retrieved from https://www.surveygizmo.com/resources/blog/purposive-sampling-101/

Gang Dong. (2013). On the Nature of Interlanguage. Research on Humanities and Social Sciences, 3(18): 42-44.

Gass, S. (1998). Integrating research areas: a framework for second language studies. Applied Linguistics, 9(2) :198-217.

Gregg, K.R. (2008). Second Language Acquisition: History and Theory. In R.E.Asher(ed). Encyclopedia of language and linguistics, pp. 3720-3726. Oxford: Elsevier.

Hair, J. F. Jr., Babin, B., Money, A. H., \& Samouel, P. (2003). Essential of business research methods. United States of America: John Wiley \& Sons.

Han, Z-H. (2003). Fossilization: From Simplicity to Complexity. International Journal of Bilingual Education and Bilingualism, 6(2): 95-128.

Han, Z-H. (2004). Fossilization: Five central issues. International Journal of Applied Linguistics, 14(2): 212-242.

Han, Z-H. (2013). Forty years later: Updating the Fossilization Hypothesis. Language Teaching, null: 133-171.

Jabatan Perangkaan Malaysia. (2010). Banci Penduduk dan Perumahan Malaysia 2010. Putrajaya: Jabatan Perangkaan Malaysia.

Kadek Adyatna Wedananta. (2017). Kesalahan Interlingual dalam Bahasa Inggeris oleh Siswa Kelas Tujuh SMP Jembatan Budaya. Jurnal IImiah Manajemen dan Bisnis, 2(1): 71-79.

Kamarul Shukri Mat Teh. (2009). Penggunaan Strategi Pembelajaran Bahasa dalam Kalangan Pelajar Sekolah Menengah Agama. Tesis Phd. Universiti Kebangsaan Malaysia.

Krashen, S., Long, M. and Scarcella, R. (1979). Age, rate, and eventual attainment in second language acquisition. TESOL Quarterly, 13 (4): 573-582. 
Krashen, S. (2003). Explorations in Language Acquisition and Use: The Taipei Lectures. Portsmouth, $\mathrm{NH}$ : Heinemann.

Lenneberg, E. (1967). Biological Foundations of Language. USA: Wiley and Sons. Liebetrau, Albert M. (1983). Measures of Association. Newbury Park: Sage Publications.

Lightbown, P. M. and N. Spada. (1999). (2nd ed.). How Languages are Learned. Oxford: Oxford University Press.

Lightbown, P. (2000). Classroom SLA research and second language teaching. Applied Linguistics, 21(4): 431-62.

Mitchell, R. and F. Myles. (1998). Second Language Learning Theories. California: Arnold.

Mohammad Hamad Al-khresheh. (2015). A Review Study of Interlanguage Theory. International Journal of Applied Linguistics \& English Literature, 4 (3): 123-131.

Mohd Majid Konting. (1990). Kaedah Penyelidikan Pendidikan. Kuala Lumpur. Dewan Bahasa dan Pustaka.

Moskovsky, C., and Ratcheva, S. (2014). L2 Fossilization: A Competence or a Performance Phenomenon. The Open Communication Journal, 8: 9-17.

Muijs, D. (2004). Doing Quantitative research in education with SPSS. London: Sage Publications.

Noor Aina Dani. (1999). Bahasa Antara di Kalangan B2: Tahap dan Fosilisasi. Dalam Monograf, Bahasa, Sastera dan Budaya Melayu. Serdang, Selangor: Penerbit Universiti Putra Malaysia. 35-57.

Noor Aina Dani dan Patarai Cholen. (2010). Cabaran Fosilisasi dalam pemerolehan bahasa Melayu bagi pelajar B2 . Dalam Melayu dalam Cabaran. Serdang, Selangor: Penerbit Universiti Putra Malaysia. 54-65.

Noor Aina Dani, Norazlina Mohd. Kiram, Mohd. Ariffin Mohd. Arif, Kamarlin Ombi, Roslan Suhailin, Sharil Nizam Sha'ri and Daisy Paul. (2019). Endangered Intergenerational Language Transmission: Evidence from the Indigenous Dusun Society of Sabah, Malaysia. Pertanika Journal of Social Science and Humanities, 27 (1): 1-12.

Noor Zuhidayah Muhd Zulkifli dan Siti Saniah Abu Bakar. (2016). Strategi Pembelajaran Bahasa Melayu dalam kalangan Pelajar di Jerman. Jurnal Kurikulum \& Pengajaran Asia Pasifik, 4(2): 10-19.

Pallant, J. (2007). SPSS Survival Manual: A step by step guide to data analysis using SPSS (3rd ed.). New South Wales: Allen \& Unwin. 
Ponto, J. (2015). Understanding and Evaluating Survey Research. Journal of the Advanced Practitioner Oncology, 6(2): 168-171.

Qian, M., \& Xiao, Z. (2010). Strategies for Preventing and Resolving Temporary Fossilization in Second Language Acquisition. English Language Teaching, 3(1): 180-183.

Richards, Jack C. (2008). Moving Beyond the Plateau from Intermediate to Advanced Levels in Language Learning. New York, NY: Cambridge University Press.

Riley, P. (2007). Introduction. In: Language, culture and identity: an ethnolinguistic perspective. Continuum, 1-20.

Romzi Ationg, Andreas Totu, Chelster S. Pudin, dan Raymond Majumah. (2018). Penggunaan Bahasa Rungus dalam Kalangan Generasi Baru (Remaja) Masyarakat Rungus di Matunggong, Sabah. Journal of Advanced Research in Social and Behavioural Sciences, 12(1): 98-110.

Rowntree, D. (1981). A dictionary of education. New York: Harper and Row Ltd.

Saraswathy a/P Pormalu @ Perumal, Rohaidah Kamaruddin, Paramasivam A/L Muthusamy, Ayuni Mohamad Bakari \& Husna Hidayah Mansor. (2017). Pembelajaran Bahasa Melayu sebagai Bahasa Kedua dalam Kalangan Pelajar Sekolah Tamil. International Journal of the Malay World and Civilisation, 5(1): 45-55.

Saric, A. (2016). Developmental Patterns in the Interlanguage Research. European Journal of Social Sciences Education and Research, 3 (2): 242-255.

Saville-Troike, M. (2006). Introducing Second Language Acquisition. Cambridge: Cambridge University Press.

Sekaran, U. (1992). Research methods for business: a skalal building approach. Ed. ke-2. New York: John Wiley \& Sons.

Sekolah Berasrama Penuh. (2017). Pentaksiran Diagnostik Akademik Sekolah Berasrama Penuh 2017. 1103/1. Hak Cipta BPSBPSK. hlm. 1-3.

Selinker, L. (1972). Interlanguage. International Review of Applied Linguistics in Language Teaching, 10 (3): 209-31.

Selinker, L. (1974). 'Interlanguage'. In Richards, J. C. (Ed.) Error Analysis. Perspectives on Second Language Acquisition. London: Longman (Applied Linguistics and Language Study).pp31-54.

Selinker, L. and Lamendella, J.T. (1979). The role of extrinsic feedback in interlanguage fossilization: a discussion of 'rule fossilization': a tentative model. Language Learning, 29(2): 363-375. 
Selinker, L. \& Lakshamanan, U. (1992). Language transfer and fossilization: The multiple effects principle. In S. M. Gass \& L. Selinker (Eds.), Language transfer in language learning (pp. 197-216). Amsterdam: John Benjamins.

Selinker, L. (1992). Rediscovering Interlanguage. United Kingdom: Longman Group.

Selinker, L. (1996). Fossilization: What We Think We Know. London: Longman Group UK Limited.

Selinker, L., and Han, Z-H. (2001). Fossilization: moving the concept into empirical longitudinal study. In C. Elder, A. Brown, E. Grove, K. Hill, N. Iwashita, T. Lumley, T. McNamara and K. O'Loughlin (eds.), Studies in language testing: experimenting with uncertainty. Cambridge: Cambridge University Press. 276-91.

Saville, T. M. (2006). Introducing Second Language Acquisition, pp. 41-42. Cambridge: Cambridge University Press.

Sharwood Smith, M. (1994). Second language learning: theoretical foundations. London: Longman.

Sidupa, C. (2018). "Indonesian Language Transfer of Students of English as a Second Language (ESL)" in The 1st Internasional Seminar on Language, Literature and Education, KnE Social Sciences, pages 5157.

Sims, W. R. (1989). Fossilization and learning strategies in second language acquisition. Minne TESOL Journal, 7: 61-72.

Skehan, P. (1994). Second language Acquisition Strategies, Interlanguage Development and Task-based Learning. In Bygate, M., A. Tonkyn and E. Williams (Eds.). Grammar and the Language Teacher. New York: Prentice Hall. 175-199.

Skehan, P. (1998). A Cognitive Approach to Language Learning. Oxford: Oxford University Press.

Sulaiman Masri, (2003). Kaedah Penyelidikan dan Panduan Penulisan. Kuala Lumpur: Utusan Publications and Distributors.

Tarone, E. (1983). On the variability of Interlanguage Systems, dlm. Applied Linguistics, 4(2): 142-163.

Tarone, E. (2001). Interlanguage. In R. Mesthrie (Eds.), Concise encyclopedia of sociolinguistics (pp. 475-81). Oxford: Elsevier.

Tarone, E. (2004). Interlanguage. In R.E. Asher (ed). 2004:1715-1719. Concise encyclopedia of sociolinguistics, pp. 1715-1719. Oxford: Elsevier. 
Tulving, E. (1972). Episodic and semantic memory. In E. Tulving \& W. Donaldson, Organization of memory (pp. 381-403). Oxford, England: Academic Press.

Vigil, N. A. and J. W. Oller, Jr. (1976). Rule fossilization: a tentative model. Language Learning, 26 (2): 281-95.

Wei, X. (2008). Implication of IL Fossilization in Second Language Acquisition. English Language Teaching, 1(1): 127-131.

Yi, Fan. (2002). Plateau of EFL Learning: A Psycholinguistic and Pedagogical Study. from http://citeseerx.ist.psu.edu/viewdoc/download?doi=10.1.1.565.6275

Yin, R.K. (1984). Case Study Research: Design and Methods. Beverly Hills, Calif: Sage Publications.

Zaidah Zainal. (2007). Case study as a research method. Jurnal Kemanusiaan, $9: 1-6$.

Zaliza Mohamad Nasira dan Zaitul Azma Zainon Hamzah. (2014). Sikap dan motivasi pelajar terhadap pembelajaran Bahasa Melayu. Procedia Social and Behavioral Sciences, 134: 408- 415. 